\title{
Shamshad Alizade* \\ IMPORTANCE OF MANAGEMENT QUALITY IN INSURANCE COMPANIES OF AZERBAIJAN AND PROVIDING ITS EFFICIENCY
}

Regardless of the field of activity, the purpose of each company is to constantly succeed and develop. But it is not easy to achieve this development in short period. In modern period, successful development and profitability of each company depends on the realization of many important factors. One of these factors is providing efficiency of management quality. The importance of management quality is evident not only in industrial and manufacturing enterprises, but also in insurance companies. Because successful activity and sustainable development of each insurance company depends on high management quality. We can note that, factors such as effective management of resources and employees, establishing public relations properly and increasing marketing activity play an exceptional role in providing efficiency of management quality in insurance companies of Azerbaijan. For this reason, the importance of management quality is very high in insurance companies of Azerbaijan and providing its efficiency is one of the most important and actual issues in modern market economy.

Keywords: Azerbaijan, insurance companies, management quality, effectiveness, development.

Tabl. 1. Lit. 10.

Peer-reviewed, approved and placed: 11.01.2020.

DOI: 10.32752/1993-6788-2020-1-223-115-120

\section{Шамшад Алізаде \\ ЗНАЧЕННЯ ЯКОСТІ УПРАВЛІННЯ В СТРАХОВИХ КОМПАНІЯХ АЗЕРБАЙДЖАНУ ТА ЗАБЕЗПЕЧЕННЯ ЙОГО ЕФЕКТИВНОСТІ}

Незалежно від сфери діяльності, метою кожної компанії с постійний успіх $i$ розвиток. Але нелегко досягти такого розвитку за короткий період. У сучасний період успішний розвиток та прибутковість кожної компанії залежсть від реалізації багатьох важсливих факторів. Одним із цих факторів є забезпечення ефективності управління якістю. Важливість якості управління очевидна не лище на промислових та виробничих підприємствах, а й у страхових компаніях. Оскільки успішна діяльність та сталий розвиток кожної страхової компанії залежить від високої якості управління. Ми можемо відзначити, що такі фактори, як ефективне управління ресурсами та працівниками, належне налагодження зв'язків з громадськістю та збільщення маркетингової діяльності відіграють виняткову роль у забезпеченні ефективності якості управління в страхових компаніях Азербайджану. 3 цієї причини в страхових компаніях Азербайджану значення якості менеджменту дуже велике, а забезпечення його ефективності є однією 3 найважливіших та актуальних проблем сучасної ринкової економіки.

Ключові слова: Азербайджан, страхові компанії, якість управління, ефективність, розвиток.

Шамшад Ализаде

\section{ЗНАЧЕНИЕ КАЧЕСТВА УПРАВЛЕНИЯ В СТРАХОВЫХ КОМПАНИЯХ АЗЕРБАЙДЖАНА И ОБЕСПЕЧЕНИЯ ЕГО ЭФФЕКТИВНОСТИ}

Независимо от сферы деятельности, целью каждой компании есть постоянный успех и развитие. Но нелегко достичь такого развития за короткий период. В современный

* Academy of Public Administration under the President of the Republic of Azerbaijan. 
факторов. Одним из этих факторов является обеспечение эффективности управления качеством. Важность качества управления очевидна не только на промышленных и производственных предприятиях, но и в страховых компаниях. Поскольку успешная деятельность и устойчивое развитие каждой страховой компании зависит от высокого качества управления. Мы можем отметить, что такие факторы, как эффективное управление ресурсами и работниками, надлежащее налаживание связей с общественностью и увеличение маркетинговой деятельности играют исключительную роль в обеспечении эффективности качества управления в страховых компаниях Азербайджана. По этой причине в страховых компаниях Азербайджана значение качества менеджмента очень большое, а обеспечение его эффективности является одной из важнейших и актуальных проблем современной рыночной экономики.

Ключевые слова: Азербайджан, страховые компании, качество управления, эффективность, развитие

1. Introduction. From the world experience, it is known that, in all companies the management quality is the basis of the management process. The efficiency of management depends on its quality. Quality is the main factor in all companies in managing resources, labor, cash, and other assets. It is known that, management quality is a complex category that combines many features. The emergence and formation of a market economy in the world, increases the necessity of management quality also in insurance companies. Today, management quality has reached a very high level in the world's most prestigious insurance companies.

It should be noted that insurance companies operating in Azerbaijan are far behind the world's most advanced insurance companies. One of the main reasons for this, is that the management quality in many insurance companies in Azerbaijan is relatively low. Providing efficiency of management quality in insurance companies operating in Azerbaijan, considered one of the most actual issues in modern period.

2. Importance of management quality in insurance companies of Azerbaijan. As we know, the formation of a market economy increases the necessity of management quality in insurance companies. For this reason management quality considered one of the main factors not only in indurstrial companies, also in insurance companies. We can say that, the management quality is in high level in the world's popular insurance companies in modern period. The management quality in companies operating in any sector of the economy in a market economy is considered part of the overall quality management policy, which defines and implements the general management function [7]. It should be noted, the high level of management quality is the necessary factor for insurance companies of Azerbaijan to succeeding as other powerful insurance companies of the world. From this point of view, the management quality is important for each insurance company operating in Azerbaijan.

Generally, increasing level of insurance services, regulation of reinsurance operations within the country's economic interests, involving professional staff by educating people and launching new insurance products that customers are interested in, are great importance in improving the management quality [1]. Besides that, activities, such as planning, organizing and controlling are required to be more effective for increasing importance of management quality in insurance companies. Planning means, defining the goals set for the insurance company, as well as to achieve these goals. The organizing activity incorporates the right management of the company and 
the right organization of the procedure [2, p. 9]. Controlling activity in insurance companies involves checking whether or not the company's overall targets are correct, and, if necessary, intervention processes. Many insurance companies' managers in Azerbaijan should pay particular attention to the proper implementation of planning, organizing and controlling processes in order to improve the management quality.

3. Providing efficiency of management quality in insurance copmanies of Azerbaijan. In modern period in many insurance companies operating in different countries improvement of management quality requires investigation of new methods, using them properly, disscussing and solving some problems [3, p. 31]. Improving management quality in Azerbaijan's insurance companies is basically based on principles such as consumerism, leadership, everyone's participation within the company, process approach and fact based decision-making [8]. In modern period it is possible to improve management quality in insurance companies of Azerbaijan with different methods. We can show these methods like that:

1. Effective formulation of internal control system: It is important to formulate internal control system with international standards as one of the key factors for achieving strategic goals in companies operating in any field of the economy. The constantly growing competitive environment in the insurance market of Azerbaijan requires the creation of a strong management structure and internal control system in the company, as well as improving the quality of insurance products offered by companies. That is why improving management quality in insurance companies is based on an effective formulation of the internal control system.

2. Establishing public relations correctly: Public relations is the practice of deliberately managing the spread of information between an individual or an organization and the public. Public relations play a great role in communicating with the company's internal and external environment, unlike other processes [4,5]. Public relations in insurance companies have many advantages. Thus, insurance companies can conveniently offer their products to market and with this way they can increase the number of clients and attract qualified personnel. Relationship with foreign companies as well as with foreign countries becomes easier and the company can get financial support from credit organizations, even in crisis situations [6]. Besides that public relations allow each company to be ready for change and respond to risks beforehand.

3. Conducting SWOT analysis properly: In market economy, it is necessary to analyze the activity of each enterprise and entrepreneurship. The main factor here is SWOT analysis. Swot analysis is not only important for industrial and manufacturing companies. It is also necessary for insurance companies that are an integral part of the service sector. The meaning of SWOT analysis was taken from its first letters. So, here it means that: S-Strength, W-weakness, O-opportunity and T-threat. An example of SWOT analysis, which is an important factor in improving management quality in insurance companies, is shown in Table 1.

4. Managing income and expenses effectively: One of the ways to improve management quality in insurance companies is managing revenue and cost effectively. As we know, one of the main goals of each company is to reduce costs and increase revenue. Insurance companies' revenues consist primarily of insurance premiums and costs incurred by insureds who suffered during an insurance event. Insurance companies can invest their revenues to the profitable fields. But, one of the important points 
to keep in mind is that, insurance companies should effectively manage their revenue, investigate the income-generating sectors of the economy, and then take that measure. Each insurance company creates insurance reserves for the insured accident beforehand. Insurance companies will pay insurance payments from insurance reserves to insureds who suffered during an insurance event. These payments is considered expenses of insurance companies. That is why, the insurance reserves should be formed properly, the loss should be assessed properly and the calculating of costs should be maintained effectively. Unnecessary costs for insurance companies may hinder their development.

Table 1. SWOT analysis in insurance companies, author's

\begin{tabular}{|c|c|c|c|}
\hline Strength & Weakness & Opportunity & Threat \\
\hline $\begin{array}{c}\text { The high quality of } \\
\text { insurance services }\end{array}$ & Weak management & $\begin{array}{c}\text { Capability to attract } \\
\text { potential customers }\end{array}$ & $\begin{array}{c}\text { Raising the state's tax } \\
\text { rates }\end{array}$ \\
\hline $\begin{array}{c}\text { High level of } \\
\text { market research }\end{array}$ & $\begin{array}{c}\text { Weak internal } \\
\text { control }\end{array}$ & $\begin{array}{c}\text { Possibility to have a } \\
\text { positive impact on the } \\
\text { development of the } \\
\text { economy }\end{array}$ & $\begin{array}{c}\text { Negative economic } \\
\text { and political } \\
\text { processes in the } \\
\text { country }\end{array}$ \\
\hline $\begin{array}{c}\text { Existing financial } \\
\text { stability in company }\end{array}$ & $\begin{array}{c}\text { Failure to invest in } \\
\text { profitable fields }\end{array}$ & $\begin{array}{c}\text { Growth and } \\
\text { development potential }\end{array}$ & $\begin{array}{c}\text { Failure to take } \\
\text { measures against the } \\
\text { emerging risks }\end{array}$ \\
\hline
\end{tabular}

5. Hiring qualified specialists in insurance field: Existence of highly qualified specialists in the insurance field is extremely important. Because qualified specialists play an important role in informing the population about insurance. People's interest to insurance increase to high level as a result of explaining the advantages of the insurance by the specialists in the insurance field. Existence of such specialists in the insurance market of Azerbaijan, of course, will effect positively to the quality of insurance services. Besides that, the detailed research of the insurance market in Azerbaijan, the establishment of relations with customers, and the selection of potential clients require a qualified and professional specialists.

6. Using the experience of developed countries in the insurance field: It is known that, management quality is in improved level in the prestigious companies of the world. So, the factors such as, establishing relations with customers in high level, effective management of staff, their excellent motivation, hiring professional qualified specialists, effective management of incomes and expenses show that management quality is in high level in these insurance companies. Besides that, there is exist qualified and professional leader with high management ability in each developed insurance companies. Making strategic decision and implementing insurance policy correctly and necessary reforms in improving management quality played great role in succeed world's most prestigious insurance companies. Using experience of developed insurance companies of the world and implementing it in insurance companies of Azerbaijan is very useful in improving management quality.

4. Conclusion. In the modern market economy, management quality is considered main factor for successful activity of companies in the any field of the economy. For this reason in modern period the necessity of management quality also occures in insurance 
companies. So, insurance companies with high management quality are steadily improving and are making great achievements. The low management quality has led many companies to lose development and even bankruptcy. It should be noted that as a main indicator of successful development, the effectiveness of management quality is also reflected in insurance companies of Azerbaijan. But despite of this, currently, many insurance companies in Azerbaijan can not develop due to the low level of management quality.

As a significant result of the research, it can be noted that, low management quality in insurance companies of Azerbaijan and besides that not developing of insurance market highly in republic stems from problems still existing in insurance field. For example, in many insurance companies the internal control system is not in satisfactory level. Occuring problems in the leader employee relations causes this issue to grow further. On the other hand, the wrong division of labor and the control process to the staff also causes occuring huge problems. Also we can note that, failure to comply to the principle of improving the quality of service by the insurance agents at a meeting with customers results loss of large potential client base. Besides that, not explaining in detail necessary information during the meeting with clients, sometimes results misunderstandings and controversy.

For this reason providing efficiency of management quality is main factor for each insurance company of Azerbaijan. As a final result we can note that, with effective formulation of internal control system, establishing public relations correctly, conducting SWOT analysis properly, managing income and expenses effectively, hiring qualified specialists in insurance field and using the experience of developed countries in the insurance field it is possible to provide efficiency of management quality in insurance companies of Azerbaijan.

1. The Ministry of Economic Development of Azerbaijan, Economic and social development concept and forecast indicators of Azerbaijan Republic for 2014 and next 3 year, Baku, August, 2013.

2. Bayramov A.V. Fundamentals of business and management, Baku, 2011, p.180

3. Ten A.V., Rumyanchev E.K., Gerasimov B.I., Sizikhin A.Y. Economic analysis of quality of insurance, Tambov, 2009, p.96

4. Azerbaycan vikimediacular: istifadrici qrupunun https://az.wikipedia.org/wiki/Public_relations

5. http://www.azhumanrights.az/az/analytics/442-pr-304ctimaiyy399tl399-399laq3991399r.html

6. http://old.azmarketing.az/m-m/133-pr/125-ictimaiyy tl - laq 1 rin-bstbnlbkl ri

7. www.aqa. az/ index.php?option $=$ com_content\&view $=$ article $\&$ id $=323$

8. http://marja.az/financial/news/insurance/item/22068-s orta- irk tl rind -mbk mm 1korporativ-idar etm -sistemi-formala mal d r-t hlil.html

9. Azerbaijan banking system: challenges and Prospects of globalization // https://cyberleninka.ru/ article/n/azerbaijan-banking-system-challenges-and-prospects-of-globalization

10. Azerbaijan Corporate Governance Project The State of Corporate Governance in Azerbaijan 2011 Project and Survey Results // https://www.ifc.org/wps/wcm/connect/56b298e6-43cb-4901-adc1587f10809213/Project\%26survey\%2Breport.pdf?MOD=AJPERES\&CVID

1. The Ministry of Economic Development of Azerbaijan, Economic and social development concept and forecast indicators of Azerbaijan Republic for 2014 and next 3 year, Baku, August, 2013.

2. Bayramov A.V. Fundamentals of business and management, Baku, 2011, p.180

3. Ten A.V., Rumyanchev E.K., Gerasimov B.I., Sizikhin A.Y. Economic analysis of quality of insurance, Tambov, 2009, p.96 
4. Azerbaycan vikimediacular: istifadrici qrupunun https://az.wikipedia.org/wiki/Public_relations

5. http://www.azhumanrights.az/az/analytics/442-pr-304ctimaiyy399t1399-399laq3991399r.html

6. http://old.azmarketing.az/m-m/133-pr/125-ictimaiyy tl - laq 1 rin-bstbnlbkl ri

7. www.aqa. az/index.php?option $=$ com_content\&view $=$ article\&id $=323$

8. http://marja.az/financial/news/insurance/item/22068-s orta- irk tl rind -mbk mm lkorporativ-idar etm -sistemi-formala mal d r-t hlil.html

9. Azerbaijan banking system: challenges and Prospects of globalization // https://cyberleninka.ru/ article/n/azerbaijan-banking-system-challenges-and-prospects-of-globalization

10. Azerbaijan Corporate Governance Project The State of Corporate Governance in Azerbaijan 2011 Project and Survey Results // https://www.ifc.org/wps/wcm/connect/56b298e6-43cb-4901-adc1587f10809213/Project\%26survey\%2Breport.pdf?MOD=AJPERES\&CVID 